\title{
Research on the Curriculum Group Construction of Public Administration Major in Universities Based on the Investigative Teaching
}

\author{
Yu Zhang* \\ Research Center for Government Governance and Public \\ Policy \\ Yangzhou University \\ Yangzhou, China \\ maggie_zhangyu@163.com
}

\author{
Yunyu Fan \\ College of Environmental Science and Engineering \\ Suzhou University of Science and Technology \\ Suzhou, China \\ 337255913@qq.com
}

\author{
Weizhong Liu \\ Research Center for Government Governance and Public Policy \\ Yangzhou University \\ Yangzhou, China \\ yzulwz@163.com
}

\begin{abstract}
This paper attempts to find solutions to break through the dilemma in which investigative teaching in universities based on single course might hinder the reforms of curriculum group construction of public administration. We studied teaching theories and analyzed difficulties in group construction of public administration such as the lack of same standard can hardly prove the curriculum relevance, the organization of teaching process lacks simplified arrangement, the allocation of teaching resource lacks pertinence, the calculation of teaching loads lacks accurateness and fairness. Finally, we demonstrate that reforming traditional curriculum setting mode and undertaking construction of the great curriculum, integrating curriculum content and compiling school-based textbook, establishing team-teaching system and adopting two lecturers or multi-lecturer mode, strengthening scientific research as a mean to improve teaching and building rese arch-based teaching group can achieve the aim of curriculum group construction. The innovation in this paper is the concept of curriculum group construction based on investigative teaching.
\end{abstract}

Keywords—public administration major; investigative teaching; curriculum group construction

\section{INTRODUCTION}

The purpose of investigative teaching in universities is to develop the thinking ability and problem-solving ability of undergraduates. The existing investigative teaching practice bases on the reform of traditional teaching mode, which mostly designed around single course and focused on applying relevant concept of investigative teaching to educational practice. However, according to continuous assessment of teaching effect, the effect of investigative teaching is positive in first course, but not conspicuously effective in following courses. The reason is that every course of investigative teaching requires independent learning, each student has to finish all kinds of social investigations, essays and reports, learning burnout will decrease compliance and learning effectiveness as the course goes on. Therefore, we should synchronously integrate course composition, teaching force and teaching resource to redesign the course setting and break course barrier to build one or several curriculum groups to implement investigative teaching.

\section{The Rationale of CuRriculum Group Construction of Public Administration Specialty}

There are abundant rationales for the conversion of investigative teaching from single course to curriculum group. According to Edward Lee Thorndike's Law of Effect, the study effect of individual or group depends on students' feeling of reaction results of teaching process. The investigative teaching effectiveness of single course tends to decline with the increase of the course and the development of study. That means students will initially be interested in investigative teaching which aims at stimulating mind which is totally different from middle school studying and interested in task form including looking up information, searching answers, doing simple street investigation and reading report. However, with the development of several investigative teaching courses, they will feel that the after-class study will aggravate and repetitive learning will increase, while the study enthusiasm and study effective will decrease. In fact, study effective is important reaction to teaching process. The awareness of low efficiency will depress students and influence learning effect.

According to Albert Bandura's Social Learning Theory, human learning is not individual study, but also group learning that influences each other. It is not only all about constructing knowledge system, but also about the formation of social attitudes and behaviors. It not always acquires from the direct consequences, which is direct experience, through their behavior, but it often learns by borrowing from other learners' behavior. Bandura's Imitation Learning Theory is a reminder to teaching reform that the process of investigative teaching is a 
process that teachers lead students to learn in which teachers and students are learners and explorers. Not only will the students have role models, teachers will have model effects on students. If teachers do not immediately adjust to the decline trend of teaching effect during the teaching process, the negative effect is that students will regard project research as the mechanical process of completing tasks, and neglect the requirements of ability development of investigative learning. Therefore, teachers should rapidly respond to the problems generated from the practice of investigative teaching.

In addition, Yerkes-Dodson Law and David P. Ausubel's Meaningful Reception Learning Theory have provided theoretical basis for the construction of curriculum group. Yerkes-Dodson Law believes that optimal level of motivation varies with the nature of the task. The effect of investigative teaching needs to seek for the best performance with the medium motivation from both teachers and students. However, during the process of investigative teaching which is focusing on the single curriculum, the motivation of teachers and students decreases with the increase of the course and the advance of the semester. Take public administration teaching as an example, in the teaching process of Introduction to Politics and Public Administration at the first year of new school, the leaning motivation of new students is strong. They can maintain moderate interest in the research task assigned by teachers, such as curriculum papers, book reports and street interviews, and they can think positively to solve the difficulties encountered in the process of task completion. In the second year, however, with the opening of major courses such as Administration Management, Public Policy, Public Organization and Public Ethics, the increasing learning tasks have weakened the learning motivation and learning effect, and the purpose of ability training is difficult to achieve. Meanwhile, the repetition of too many knowledge points cause the emergence of declines burnout and decrease in homework quality which affects the realization of the teaching achievement, and further leads to the weakening of teachers' motivation. The construction of curriculum group helps to reduce the repeated teaching of knowledge points and homework assignments, but improve the requirements for homework quality and make a beneficial adjustment to the motivations of both the teachers and the students. As to Ausubel, students' learning process is always inseparable from the receptive learning. It is the process of substantial connection between old and new knowledge, previous knowledge structure and knowledge reserve can beneficially push the following study, and form more abundant new knowledge structure. This is true even in investigative teaching practice. The connection between new and old knowledge needs to be reasonable, logical and bound, and too many overlap between each other will affect the actual learning effect.

\section{DifFiculties in CURRICUlum GROUP CONSTRUCTION} of Public Administration Specialty

\section{A. Curriculum Relevance is Hard to be Proved for the Lack of Same Standard}

Firstly, curriculum group construction needs to integrate related courses. However, the problem is that the knowledge points of each course of public administration specialty have relevance and overlaps. For example, the Public Goods Theory will appear repeatedly in Public Administration, Public Economics, Administrative Management and Introduction to Public Service Administration. The political philosophy of utilitarianism is mentioned in Principles of Political Science, History of Western Political Theory, Public Administration, and History of Western Administrative Theory; Not in My Back Yard is taught both in Public Policy Analysis and Sociology. If curriculum group integrates according to related courses which confirmed by repeated knowledge points, the boundary of the knowledge points will be unsaturated, and easy to cross with each other. It is hard to find a suitable category of group, the operability of curriculum group division will not be strong.[1] If the curriculum classifies according to the future application of courses, it is hard to construct curriculum group. Because the application is not explicit, moreover, some basic courses are the starting point of the knowledge construction of other courses, such as Introduction to Law, Principles of Political Science, Public Service Administration, History of Western Political Theory and History of Western Administrative Theory. If the problem-orientated teaching design principle wants to integrate courses with presupposed subject, it requires freshmen to fully understand teachers' project design, and form suitable learning expectation, but this is difficult for those who has just stepped out of the test-taking mode, and is not conducive for the formation of proper learning motivation.

\section{B. The Organization of Teaching Process Lacks Simplified Arrangement}

Although the process of investigative teaching promotes the interaction between teachers and students and highlights student's main role, and focuses on the improvement of students' learning ability, problem-solving ability, team cooperation ability and innovation ability, the organization of the teaching process is still dominated by teachers. It requires teachers' wisdom and classroom control ability,[2] but the construction of curriculum group broke the boundaries between courses, which is a cooperative process to carry out teaching design, adopt a variety of teaching methods, cope with students' problems, guide students to think, cultivate students' problem-solving ability and tap their potential. That is to say, the construction of curriculum group is not as simple as teaching a single course, it needs to form a teaching team, and is a process of collective lesson preparation, collective teaching and collective assessment of students. So the first problem is who will lead the teaching team? The second problem is whether the teaching process is to divide the course group into a number of modules for different teachers, or in the way of collective teaching. The third question is, considering curriculum group teaching is attended by several teachers, the pace and efficiency of classroom teaching will change, and the structure of the classroom will be loose. How can we avoid procrastination by improving the efficiency of teaching? The 
forth question is, since the administrative department requires the teacher to grade students' score according to the course, how to make correspond change on students' assessment methods after adopting curriculum group teaching? The fifth question is how to evaluate teachers? Whether the individual assessment result belongs to the teaching team or calculates separately?

\section{The Allocation of Teaching Resources Lacks Pertinence}

The course group construction is not simply a combination of the same category. In addition to the curriculum integration, it is necessary for the school to provide the corresponding teaching resources.[3] For example, in the use of teaching materials, we should acknowledge teachers' selected teaching textbooks, compiled lecture notes and self-set learning content. Library should help the construction of curriculum group according to the reading list, image data set by the teachers, and purchase abundant student's learning materials. At present, however, the school library procurement system is disconnect with the teaching requirements of teachers, while in the implementation process of curriculum group of investigative teaching, students' self-study link is indispensable. Meanwhile, library should draw on the model of foreign universities, setting up some group discussion rooms for the demands of group study, brainstorming, topic discussion and debate. The lack of this facility highlights the barriers between teaching departments and assist departments. In arrangement of teaching environment, the placement of stationary desks and chairs of traditional classroom is the product of lecturing mode in class teaching system. It is not conductive to the interaction between teachers and students, as well as group discussion. The placement of the platform is also not conductive to group teaching and not adapt to the curriculum group mode of investigative teaching. In teaching support system, multimedia teaching is too single to meet the needs of curriculum group of investigative teaching which requires projector, case discussion room, simulation functional office hall, multi-port network classroom (students' computers are accessible), video equipment(meet the needs of micro-teaching and micro-lesson), and wireless microphone for teachers and students.

\section{The Calculation of Teaching Workload Lacks Accurateness and Fairness}

The curriculum group construction of investigative teaching will integrate courses assigned in different credits and periods, and different titles should be contained in the structure of teaching group. In the current salary distribution system of college teachers, the calculation of period remuneration mainly stratifies according to the level of professional title.[4] Then, there will be differences in teachers' remuneration in the same curriculum group. Mangers should consider how to motivate teachers. In terms of the same curriculum group, teachers are all involved in the teaching activities including teaching design, teaching implementation and evaluation of students' performance together, they have all made contribution to teaching reform, but there was differences in pay. In addition, the calculation of teaching load of teaching group, which promotes the curriculum group construction of investigative teaching, is the same as teachers who are engaged in investigative teaching of single course. This would weaken teachers' motivation to participate in curriculum group teaching, and return to the investigative teaching mode of a single course and even to the traditional single teaching mode. It is not conducive to the promotion of teaching reform. The key to the problem is that even if the related policy subject has realized innovativeness and advancement of curriculum group of investigative teaching, and carried out the reform of class reward system, it is still hard to achieve the real fairness. Because there are differences in contributions and undertaken tasks in a teaching team, every teacher's role is also different. For policy makers, whether the accounting aims at individuals or aims at the entire teaching group? Do they need to think about difference and balance the difference between pay and performance? Is differential treatments needed for the majors and teachers which explore the curriculum group construction? These problems often conflict in practical operation.

\section{STRATEgIES FOR CURRICUlum GROUP CONSTRUCTION of Public Administration Specialty}

\section{A. Reforming Traditional Curriculum Setting Mode and Undertaking Great Curriculum Construction}

Great curriculum construction is considering all specialized courses as a great curriculum that is equal to general courses and public discipline basic courses. In terms of the specialized courses of undergraduate teaching of public administration, the colleges, departments and groups of the great course are in charge of the construction methods, teaching materials use, personnel composition and rating methods of the curriculum group. The curriculum group in the great course cannot focus on the elimination of repeated knowledge points. Instead it can integrate the original discipline basic courses, compulsory courses and professional elective courses, such as the Introduction to Law (discipline basic course) and Administration Law, Economic Law (major compulsory course) and Civil Service System (major elective course) can form a law curriculum group. Public Administration, Administrative Management, Administrative Organization (discipline basic course) and Introduction to Public Utilities Management (major compulsory course) and City Management, Introduction to Non-profit Organizations, Public Administration Case Analysis, Frontiers of Contemporary Public Administration Theory, Western Administrative Theory (major elective courses) can form a public administration curriculum group. Principles of Management, Human Resources Management of Public Sector (discipline basic course) and Secretarial Management, Management Intellectual History, Management Psychology, Leadership Science (major elective courses) can form a management curriculum group. Public Economics (major elective courses) and Microeconomics, Macroeconomics (major compulsory courses) can form the economics curriculum group. Principles of Political Science (discipline basic course) and Western Political Theory, Comparative Politics System, Political Culture (major elective courses) can form a political science curriculum group. Public Policy Science (discipline basic course) and Public Policy Analysis, Contemporary Chinese government Process and Local government (major compulsory courses) can form a policy curriculum group. Sociology (major compulsory course) and Social Work, Communication (major elective course) can form a sociology curriculum group. The credit weight of each curriculum group is set according to the cultivation objectives 
of talents and the connotation of curriculum group. The classification method of this curriculum group is not only conducive to the integration of knowledge points, but also conducive to the communication between teachers of relevant disciplines. They can adjust teaching contents and teaching plans timely. Meanwhile, the major courses consisted of curriculum groups supported by module segmentation can make public administration graduates clearly aware of what they have learned in school and make clear description when they cope with recruitment questions of human resource managers in future. This has solved the problem that the graduates of public administration majors cannot give details of their major. Moreover, the curriculum group construction included in the major great course is similar to project management. The learning experience of students is a process of learning project management.

\section{B. Integrating Curriculum Content and Compiling School-based Textbook}

The curriculum group construction should promote all-around course integration, the department of teaching administration encourages the curriculum group to use self-compiled lectures and school-based materials, rather than make minor adjustments of the original teaching content of courses under the title of the curriculum group. Therefore, the teaching team needs to be free from the textbooks of the high education edition, reread the original course content, and recompile the teaching materials used in the course group.[3] The compilation of school-based textbooks focuses on the coordination and systematization of the sub-courses of curriculum group. For example, public administration course group can compile textbooks around a range of issues, such as "What is public administration? Who will do the public administration? What does public administration manage? How do they manage it? How do you measure the results of public administration? Who will supervise public administration? How to supervise?", and absorb disciplinary knowledge of Public Administration, Administrative Management, Administrative Organization, Introduction to Public Utilities Management, City Management, Introduction to Non-profit Organization, Public Administration Case Analysis, Frontiers of Contemporary Public Administration Theory, Western Administrative Theory into above problems, and then refine it. In addition, the traditional problems and classical knowledge, which will be involved in different curriculum groups, should communicate between curriculum groups, and make a preliminary analysis. For example, put social issues in sociology course group, put governance related content in politics curriculum group, put the content related to the activity of public policy in public policy course group, the same problem should be avoided when teaching material is compiled by other groups. If we should study the same social hot issue comprehensively, it cannot be considered in the compilation of school-based textbooks and be left in the cooperation of curriculum group in teaching process. In the process of compilation of school-based teaching materials, the basic thoughts and policy should not deviate from the regulations of education ministry, but the writing of the case requires a combination of local governance instance in order to make the research object within reach which can enhance the realistic significance of the study. Besides textbooks, appropriate dynamic teaching resources are also needed, such as images, interview records, video, etc. In preparation stage, the teaching team collects local data by itself.

\section{Establishing Team-teaching System and Adopting \\ Double-lecturer or Multi-lecturer Mode}

The curriculum group teaching needs to adopt double-lecturer or multi-lecturer teaching mode. If the curriculum group is divided into several modules, each teacher is responsible for one of the modules and takes turns to teach, we will lose the significance of the curriculum group teaching. Curriculum group teaching must be a teaching process of team cooperation. Certainly, the teaching team of a course group can be composed of 3 to 5 people, and the teaching process does not need to be attended by all teachers every time, double-lecturer or multi-lecturer teaching mode can be adopted. Double-lecturer mainly refers to two teachers appeared on the platform at the same time, they can adopt role-play double lecturers, or homogeneous double lecturers, or complementary double lecturers. On the one hand, this can improve students' interest. On the other hand, it can also break the barrier of the course, and provide multidimensional and comprehensive perspective to students. Two teaches can divide the work, such as the classification of theory and practice, they teach, answer questions and assign homework separately, and put forward subjects that need to be studied together. The function and role of teachers in double-lecturer mode are merely the same. Multi-lecturer mode centers on one teacher. Other teachers do not stand on the platform, but mainly appear when students give classroom presentations or report research questions. The lecturers' main selection basis is the aspect the subject focused on, and the other teachers make supplementary comments and ask further questions. The advantage of multi-lecturer mainly lies in the strengthening of communication and interaction between teachers within the group, teachers and students, which make the learning and teaching connection more closely. It is also beneficial to use the research team to promote the teaching team. Students can learn process of all kinds of interviews in college learning stage, which is also conducive to the cultivation of their application ability.

\section{Strengthening Scientific Research as a Mean to Improve Teaching and Building Research-based Teaching Group}

The curriculum group construction needs a good teaching team to complete the teaching task. The teaching team had better to be a research teaching team, combining teaching and research. Due to the strong consistency curriculum group's discipline orientation, it will be helpful to improve the teaching effect if they cooperate in scientific research. If college teachers are not strong in their own scientific research ability, it is very difficult to guide students to study based on investigation with the spirit of scientific research.[5] The purpose of a good college teacher is not to do research, it is necessary to improve knowledge level and ability to grasp academic frontiers and have a demonstration effect on students. Teachers' high attainments in scientific research will give students more enlightenment and thinking. Similarly, a good teaching team should be a research team. The research teaching team needs to meet three requirements. First, the teaching team should have gradient on age structure, with the combination of all ages, because of the liquidity of the college teachers. The 
flow of teachers cannot affect the cooperation of a teaching team. They need teachers as the backup. Initially, they can take on lighter teaching tasks and then adjust according to the flow of teachers. Secondly, teachers should be complementary in knowledge structure. Their research direction in the scientific research is almost the same, but their knowledge structure should reflect difference, so that teaching team can act as a role model and let students perceive their knowledge span in the process of teaching. Thirdly, the teaching team needs to share the scientific research results, and be willing to share the experience of scientific research with the students. Only in this way can the teaching team guide students to explore solutions to problems. Investigative teaching is ultimately about helping students to learn to think and find ans wers. Therefore, it is very important for teaching team to share the values. If they cannot use the sincere attitude to lead the teaching with scientific research, the perfunctory learning of students will be predictable. The teaching team should establish a weekly preparation system, compile the teaching plan of the curriculum group, and reflect on teaching.

\section{CONCLUSION}

Overall, our study reviewed the theory of the curriculum group construction of public administration specialty, analyzed the difficulties in construction, and finally put forward several strategies. Clearly, theoretical research illustrated that the increasing of lessons will weaken the learning motivation and group study will trigger model effect, which is beneficial to investigative teaching. Therefore, curriculum group can effectively solve the problem. However, integration of courses, the organization of teaching process, the allocation of teaching resources and the calculation of workload are main problems, which have slowed down the construction. In order to promote the curriculum group construction, we should pay more attention on course reform and team building.

\section{REFERENCES}

[1] Li huixian, "On the construction of college curriculum groups", Jiangsu High Education, pp. 73-75, November 2006, (In Chinese)

[2] Zhang Jingsen, Du Zhenchuan, Zhou Junjie, Xu Yun, Zhang Jing, "Several problems in the theoretical construction and practice of college curriculum groups,” Modern Education Science, pp.64-69, September 2015, (In Chinese)

[3] Chen Changhong, "Exploration and practice of undergraduate teaching mode based on research-based teaching-— taking "signal and system" as an example,” Science and Education Guide, pp.127-129, January 2017, (In Chinese)

[4] Zhao Hong, "Reform of research teaching and university teaching methods," Advanced Education Research, pp.71-75, February 2006, (In Chinese)

[5] Peng Xiantao, "An analysis of the concept of research teaching in university,” Education Guide, pp.56-58, March 2008, (In Chinese) 